\title{
Ovarian cancer and $\mathrm{ABO}$ blood groups
}

\author{
Jane Henderson, Valerie Seagroatt, Michael Goldacre
}

\begin{abstract}
Objective-To determine whether the distribution of ABO blood groups in women with ovarian cancer differs from that in the general population in a large, defined English region.
\end{abstract}

Design-Analysis of record abstracts of hospital care held in the Oxford record linkage study supplemented with data from the Oxford cancer registry.

Setting-Oxford Regional Health Authority area.

Subjects-A total of 1261 women who had ovarian cancer between 1968 and 1986 with ABO blood groups recorded on the Oxford Record Linkage Study and cross checked against the cancer registry comprised the study group.

Measurements and main results-The relative incidence of $A: O$ and $B: O$ blood groups in women with ovarian cancer were compared with the general population in the same region. Ovarian cancer was more common in women of blood group $A$ than in others, with a relative incidence of $1 \cdot 17$. In particular, adenocarcinomas were the most common type of tumour and were associated with blood group $A$. The association was more striking in married women than in single women probably reflecting differences associated with parity.

Conclusion-The association between ABO blood groups and ovarian cancer found in this English population is similar in size to that reported from several other populations. Childbearing is known to reduce the risk of ovarian cancer and our findings suggest that the blood group association may be most apparent in married, parous (that is, relatively low risk) women.

f Epidemiol Community Health 1993; 47: 287-289

Unit of Health Care Epidemiology, Department of Public Health and Primary Care, University of Care, University of Headington, Oxford OX3 $7 \mathrm{LF}$

J Henderson

V Seagroatt

$M$ Goldacre

Correspondence to: Ms Jane Henderson

Accepted for publication November 1992
About 4000 women die each year from ovarian cancer in England. ${ }^{1}$ It is the commonest cause of death from cancer of the female genital tract in England and its prognosis is generally poor. ${ }^{23}$ Death rates increased in England during the first half of this century but have levelled off in recent decades. ${ }^{4}$ It is commoner in western Europe and north America than in Japan, China, India, and south America. ${ }^{6}$ The aetiology of ovarian cancer is largely unknown and its study is complicated by the many different histological types of tumour. There is a protective effect of parity and of the use of oral contraceptives. ${ }^{78}$
For some cases, it has long been suspected that there is a genetic influence. Clustering within families occurs. McGowan, for example, found that women with ovarian cancer were more likely than controls to have relatives with cancer of the female reproductive organs. ${ }^{9}$ There is also evidence that breast cancer and ovarian cancer may occur together in families more often than expected by chance. ${ }^{10}$ Several studies from elsewhere have suggested an association between ovarian cancer and blood group $\mathrm{A}$ as a genetic marker. ${ }^{11-14}$ We are not, however, aware of large scale, population based investigations of this association in an English population. The Oxford Record Linkage Study is probably one of the largest datasets available which includes data on $\mathrm{ABO}$ blood groups and clinical disease and we therefore used its data to examine this relationship in Oxford.

\section{Method}

PATIENTS AND RECORDS

The Oxford Record Linkage Study (ORLS) is a collection of brief statistical abstracts of hospital records in a defined population in the Oxford region. When the patient's blood group is recorded in the case notes during an inpatient stay, the data have been routinely coded on the ORLS abstract. In the present study, if blood group was not recorded on the record of ovarian cancer, where available it was taken from other records relating to the woman. The study included women with a primary diagnosis of malignant neoplasm of the ovary (International Classification of Diseases' codes 183.0 in the 8th and 9th revisions) admitted to National Health Service hospitals in the two districts of the Oxford region covered by data collection between 1968 and 1974 and the six districts covered by data collection between 1975 and 1986. The diagnosis of ovarian cancer was cross checked with the Oxford region's cancer registry and information on the histological type of the tumour was obtained from that source.

Data on blood groups for controls were available from three sources. These were: all patients in the ORLS whose blood group had been recorded between 1968 and 1978; all patients in the ORLS with a blood group recorded between 1979 and 1984; and blood donors in the Oxford region in 1988. ABO blood group distribution in each source were very similar, and we used the inpatient data for 1979-84 as the control data in the statistical analyses which follow.

STATISTICAL METHODS

The blood group distribution of the cases and the control population were compared by the method 
Table I Blood group distributions for cases of ovarian cancer in relation to histological type

\begin{tabular}{|c|c|c|c|c|c|c|c|c|c|}
\hline \multirow[b]{2}{*}{ Histological type } & \multirow[b]{2}{*}{ Total } & \multicolumn{4}{|c|}{ No (\%) with stated group } & \multirow{2}{*}{$\begin{array}{l}\text { Relative } \\
\text { incidence } \\
A: O\end{array}$} & \multirow{2}{*}{$\begin{array}{l}95 \% \\
\text { confidence } \\
\text { interval }\end{array}$} & \multirow{2}{*}{$\begin{array}{l}\text { Relative } \\
\text { incidence } \\
B: O\end{array}$} & \multirow{2}{*}{$\begin{array}{l}95 \% \\
\text { confidence } \\
\text { interval }\end{array}$} \\
\hline & & $O$ & $A$ & $B$ & $A B$ & & & & \\
\hline All ovarian cancers & 1261 & 518 & 587 & 114 & 42 & $1 \cdot 17^{\star}$ & $(1 \cdot 0,1 \cdot 3)$ & $1 \cdot 10$ & $(0.9,1.4)$ \\
\hline $\begin{array}{l}\text { (\%) } \\
\text { Adenocarcinoma }\end{array}$ & $\begin{array}{l}(100 \cdot 0) \\
1011\end{array}$ & $\begin{array}{l}(41 \cdot 1) \\
420\end{array}$ & $\begin{array}{l}(46 \cdot 6) \\
465\end{array}$ & $\begin{array}{c}(9 \cdot 0) \\
93\end{array}$ & $\begin{array}{l}(3 \cdot 3) \\
33\end{array}$ & $1 \cdot 15^{\star}$ & $(1 \cdot 0,1 \cdot 3)$ & $1 \cdot 10$ & $(0.9,1.4$ \\
\hline (\%) & $(100 \cdot 0)$ & $(41 \cdot 5)$ & $(46 \cdot 0)$ & $(9 \cdot 2)$ & $(3 \cdot 3)$ & 2.8 & $(2,0,2)$ & & $(0,2,1$ \\
\hline $\begin{array}{l}\text { Anaplastic tumours } \\
(\%)\end{array}$ & $\begin{array}{c}73 \\
(100 \cdot 0)\end{array}$ & $\begin{array}{c}32 \\
(43 \cdot 8)\end{array}$ & $\begin{array}{c}33 \\
(45 \cdot 2)\end{array}$ & $\begin{array}{l}8 \\
(11 \cdot 0)\end{array}$ & $\begin{array}{c}0 \\
(0)\end{array}$ & $1 \cdot 07$ & $(0 \cdot 6,1 \cdot 8)$ & $1 \cdot 25$ & $(0 \cdot 6,2 \cdot 7)$ \\
\hline $\begin{array}{l}\text { Special ovarian tumours } \\
(\%)\end{array}$ & $\begin{array}{c}47 \\
(100 \cdot 0)\end{array}$ & $\begin{array}{l}21 \\
(44 \cdot 7)\end{array}$ & $\begin{array}{c}20 \\
(42 \cdot 5)\end{array}$ & 2 & $\begin{array}{c}4 \\
(8 \cdot 5)\end{array}$ & 0.99 & $(0 \cdot 5,1 \cdot 8)$ & $0 \cdot 47$ & $(0 \cdot 1,2 \cdot 1)$ \\
\hline $\begin{array}{l}\text { Other epithelial tumours } \\
(\%)\end{array}$ & $\begin{array}{c}23 \\
(100 \cdot 0)\end{array}$ & $\begin{array}{c}11 \\
(47 \cdot 8)\end{array}$ & $\begin{array}{c}9 \\
(39 \cdot 1)\end{array}$ & $\begin{array}{c}1 \\
(4 \cdot 3)\end{array}$ & $\begin{array}{c}(0.7) \\
2 \\
(8 \cdot 7)\end{array}$ & $0 \cdot 85$ & $(0 \cdot 3,2 \cdot 1)$ & $0 \cdot 49$ & $(0 \cdot 1,3 \cdot 7)$ \\
\hline $\begin{array}{l}\text { Unspecified } \\
(\%)\end{array}$ & $\begin{array}{l}107 \\
(100 \cdot 0)\end{array}$ & $\begin{array}{c}34 \\
(31 \cdot 8)\end{array}$ & $\begin{array}{c}60 \\
(56 \cdot 1)\end{array}$ & $\begin{array}{l}10 \\
(9 \cdot 3)\end{array}$ & $\begin{array}{c}3 \\
(2 \cdot 8)\end{array}$ & $1 \cdot 83^{\star}$ & $(1 \cdot 2,2 \cdot 8)$ & $1 \cdot 47$ & $(0 \cdot 7,3 \cdot 0)$ \\
\hline
\end{tabular}

Controls were the ORLS patients admitted during 1979-84 ${ }^{\star}$ Relative incidence differs from one at $5 \%$ level

described by Mourant ${ }^{15}$ citing Woolf. The ratio of the frequency of blood group $A$ to $O$ in the cases was calculated first, followed by the ratio of blood group $\mathrm{A}$ to $\mathrm{O}$ in the controls. The ratio of the $A / O$ ratio for the cases to that for the control population was then calculated and, following Mourant, this was termed the relative incidence of A. In effect, this provides a measure of relative incidence of $A$ to $O$ blood groups in the cases after adjusting for the levels of $\mathrm{A}$ and $\mathrm{O}$ in the control population. If the cases and controls had the same blood group distributions in respect of $A$ and $O$, then the relative incidence would be one. A $\chi^{2}$ statistic for the significance of the difference of the estimated relative incidence from one and its approximate confidence interval were calculated. Similar calculations were undertaken to compare the relative incidences of blood group $\mathrm{B}$ to $\mathrm{O}$ in cases and controls.

The heterogeneity of relative incidences estimated in subgroups of the cases (for example, comparing histological types, marital status groups, and parity groups) was assessed by $\chi^{2}$ statistic. ${ }^{15}$ Relative incidences for subgroups of the cases were combined by taking their weighted geometric mean with weights taken as the reciprocal of the variances of the individual incidences.

\section{Results}

Data on 1261 women with ovarian cancer and recorded $\mathrm{ABO}$ blood groups were available for analysis. As expected, most tumours were adenocarcinomas. Using the cancer registry's nomenclature, there were 1011 adenocarcinomas $(80.2 \%$ of the total), 73 tumours recorded as anaplastic $(15 \cdot 8 \%), 47$ "special ovarian" tumours $(3.7 \%)$ which were mainly granulosa cell tumours, 23 "other epithelial" tumours (1.8\%) which included sarcomas, and the histology was unspecified in 107 patients $(8.5 \%)$.

Table II Blood group distribution of general hospitalised population (ORLS 1979-84) by place of birth

\begin{tabular}{|c|c|c|c|c|c|}
\hline & \multicolumn{4}{|c|}{ No (\%) with stated group } & \multirow[b]{2}{*}{ Total } \\
\hline & $O$ & $A$ & $B$ & $A B$ & \\
\hline $\begin{array}{l}\text { South and Central England } \\
\text { (\%) } \\
\text { North England and Scotland } \\
\text { (\%) } \\
\text { Wales } \\
\text { (\%) } \\
\text { Ireland (North and South) } \\
\text { (\%) } \\
\text { Other countries } \\
(\%) \\
\text { Not known } \\
(\%)\end{array}$ & $\begin{array}{c}29703 \\
(44 \cdot 0) \\
4810 \\
(48 \cdot 6) \\
794 \\
(46 \cdot 8) \\
1922 \\
(53 \cdot 7) \\
2860 \\
(41 \cdot 9) \\
9800 \\
(44 \cdot 6)\end{array}$ & $\begin{array}{c}30320 \\
(44 \cdot 9) \\
3957 \\
(39 \cdot 9) \\
686 \\
(40 \cdot 4) \\
1217 \\
(34 \cdot 0) \\
2429 \\
(35 \cdot 5) \\
9557 \\
(43.5)\end{array}$ & $\begin{array}{l}5454 \\
(8 \cdot 1) \\
887 \\
(8 \cdot 9) \\
161 \\
(9 \cdot 5) \\
359 \\
(10 \cdot 0) \\
1205 \\
(17 \cdot 6) \\
1950 \\
(8 \cdot 9)\end{array}$ & $\begin{array}{r}1999 \\
(3 \cdot 0) \\
251 \\
(2 \cdot 5) \\
56 \\
(3 \cdot 3) \\
83 \\
(2 \cdot 3) \\
338 \\
(4 \cdot 9) \\
666 \\
(3 \cdot 0)\end{array}$ & $\begin{array}{c}67476 \\
(100 \cdot 0) \\
9905 \\
(100 \cdot 0) \\
1697 \\
(100 \cdot 0) \\
3581 \\
(100 \cdot 0) \\
6832 \\
(100 \cdot 0) \\
21973 \\
(100 \cdot 0)\end{array}$ \\
\hline
\end{tabular}

The blood group distributions and relative incidences for groups $\mathrm{A}$ and $\mathrm{B}$ by histological tumour type are shown in table $\mathrm{I}$. The relative incidences of $A$ and $B$ were greater than one in the patients with ovarian cancer. That for blood group A differed significantly from one $\left(\chi^{2}=7 \cdot 0\right.$; $\mathrm{df}=1 ; \mathrm{p}<0.01)$. The confidence intervals for the relative incidences for $\mathrm{B}$ were based on many fewer cases and were much wider than those for blood group A.

The relative incidence of blood group $\mathrm{A}$ in patients with adenocarcinoma was 1.15 (95\% confidence interval $1 \cdot 0,1 \cdot 3)$. Although special ovarian tumours and other epithelial tumours had lower relative incidences for $\mathrm{A}$ and $\mathrm{B}$, numbers were small, the confidence intervals were wide, and these differences were not significant. Overall, the differences found in the relative incidences for both $\mathrm{A}$ and $\mathrm{B}$, comparing different histological types, were not significant $\left(\chi^{2}\right.$ for $\mathrm{A}: \mathrm{O}=5 \cdot 4$, $\mathrm{B}: \mathrm{O}=2 \cdot 7,4$ degrees of freedom).

In the general population, even within the United Kingdom, ABO blood group distributions are strikingly associated with place of birth. In the ORLS population the $\mathrm{A}: \mathrm{O}$ ratio was highest in people born in south and central England (table II). We therefore examined the blood group association for those born in south or central England separately. The place of birth was recorded for 1117 of the 1261 patients with ovarian cancer $(89 \%)$. Of the 1117,819 women were born in south and central England. Of these, 379 were blood group $O$ and 440 were blood group $\mathrm{A}$. The relative incidence of $\mathrm{A}: \mathrm{O}$ in patients with ovarian cancer born in south and central England was $1 \cdot 16$ (95\% confidence interval $1 \cdot 0$, 1.3).

The relative incidences of blood group A:O in women with ovarian cancer subdivided by marital status, adjusted for age, are shown in table III. The relative incidence for single women was lower than that for married women, and that for divorced and widowed women was intermediate between the single and married women. These differences were statistically significant. Restricting our analysis to those born in south or central England, single women still had the lowest relative incidence but the numbers were smaller, the variation was reduced, and the differences no longer significant. We assumed that marital status was a proxy for parity in respect of the blood group association. We therefore sought data on parity from the ORLS files. Parity has not been regularly recorded on gynaecological records in the ORLS and was available for only $349(29 \%)$ of the cases. Since information on parity was not available for 
Table III Assaciation between blood group $A$, marital state, and parity adjusted for age

\begin{tabular}{|c|c|c|c|c|c|c|c|}
\hline Variable & Total women & $\begin{array}{l}\text { Bloo } \\
O\end{array}$ & roup & $\begin{array}{l}\text { Relative } \\
\text { incidence }\end{array}$ & $\begin{array}{l}95 \% \text { confidence } \\
\text { interval }\end{array}$ & $\begin{array}{l}\chi^{2} \text { for } \\
\text { comparison with } \\
\text { controls }(d f=1)\end{array}$ & $\begin{array}{l}\chi^{2} \text { for differences } \\
\text { between marital } \\
\text { states/parity } \\
\text { groups }(d f=3)\end{array}$ \\
\hline $\begin{array}{l}\text { Marital state: } \\
\text { Single } \\
\text { Married } \\
\text { Widowed } \\
\text { Divorced } \\
\text { Weighted average }\end{array}$ & $\begin{array}{r}140 \\
771 \\
218 \\
77 \\
1206\end{array}$ & $\begin{array}{r}70 \\
296 \\
98 \\
32 \\
496\end{array}$ & $\begin{array}{r}54 \\
376 \\
93 \\
35 \\
557\end{array}$ & $\begin{array}{l}0.81 \\
1 \cdot 27 \\
1 \cdot 01 \\
1 \cdot 13 \\
1 \cdot 18\end{array}$ & $\begin{array}{l}0 \cdot 6,1 \cdot 2 \\
1 \cdot 1,1 \cdot 5 \\
0 \cdot 7,1 \cdot 4 \\
0 \cdot 7,1 \cdot 9 \\
1 \cdot 0,1 \cdot 3\end{array}$ & $\begin{array}{l}1 \cdot 3 \\
9 \cdot 1^{\star} \\
0 \cdot 0 \\
0 \cdot 2 \\
5 \cdot 7\end{array}$ & $12 \cdot 9^{\star}$ \\
\hline $\begin{array}{l}\text { Parity: } \\
0 \\
1 \\
2 \\
3+ \\
\text { Weighted average }\end{array}$ & $\begin{array}{r}84 \\
83 \\
101 \\
81 \\
349\end{array}$ & $\begin{array}{r}37 \\
31 \\
43 \\
34 \\
145\end{array}$ & $\begin{array}{r}33 \\
44 \\
43 \\
40 \\
160\end{array}$ & $\begin{array}{l}0.98 \\
1.41 \\
1.01 \\
1 \cdot 16 \\
1 \cdot 12\end{array}$ & $\begin{array}{l}0.6,1 \cdot 6 \\
0.9,2.3 \\
0.7,1.6 \\
0.7,1.9 \\
0.9,1.4\end{array}$ & $\begin{array}{l}0 \cdot 1 \\
2 \cdot 1 \\
0 \cdot 0 \\
0 \cdot 3 \\
1 \cdot 0\end{array}$ & $5 \cdot 5$ \\
\hline
\end{tabular}

the controls, we used the blood group data on single women in the ORLS files as controls for nulliparous cases; and we used the blood group data on married women as controls for parous cases. As expected, nulliparous women had the lowest relative incidence but these differences were not statistically significant (table III). We analysed the data on blood group, marital status, and parity again confining the analysis to women born in south and central England with the same result but a larger confidence interval.

\section{Discussion}

Mourant combined data on a total of 3175 cases from 24 studies in different populations worldwide to obtain a relative incidence for blood group $\mathrm{A}: \mathrm{O}$ of $1 \cdot 23 .{ }^{15}$ Bjorkholm found a relative incidence for blood group A:O of 1.19 in a study of 1930 women from a single centre in Sweden (where the prevalence of blood group $\mathrm{O}$ in the general population is lower than that in England).${ }^{13}$ Our relative incidence for $\mathrm{A}: \mathrm{O}$ in women with ovarian cancer in a fairly homogeneous English population was $1 \cdot 17$ ( $95 \%$ confidence limits $1.0,1.3)$. The relative excess of women with blood group $\mathrm{A}$ in association with ovarian cancer is therefore remarkably similar in different industrialised populations.

One suggested mechanism by which women of blood group A might be at higher risk of cancers involves diminished immunological surveillance. ${ }^{16}$ Some tumours, notably of the stomach and colon, express the Forssmann antigen which is structurally similar to the A antigen determinant. People with blood groups other than A produce anti-A antibodies. Because of structural similarity, these antibodies might also attack precancerous or cancerous cells expressing the Forssmann antigen. Thus, some people of blood group A may have a diminished immune response to the tumour.

Childbearing is known to reduce the risk of developing ovarian cancer. Our findings on possible differences between marital states (as a proxy for parity) in the association between blood group and ovarian cancer are not conclusive, but they suggest that the association may be most evident in women with a comparatively low risk of developing ovarian cancer, that is, married parous women. Investigators studying other, more discriminating genetic markers, such as HLA antigens, may find it useful to subdivide patient populations by levels of known risk, such as parity, in assessing the genetic contribution to the disease.

We would like to thank Jennie Fairweather for her computing assistance and Liza Brandon for secretarial help. The Unit of Health Care Epidemiology is part of the Department of Public Health and Primary Care, University of Oxford. The Unit is funded by the Department of Health; the Oxford Record Linkage Study is funded by Oxford Regional Health Authority.

1 Office of Population Censuses and Surveys. 1990 Mortality statistics by cause. London: HMSO, 1991.

2 Office of Population Censuses and Surveys, Cancer Research Campaign. Cancer statistics. London: HMSO, 1981 .

3 Clayton SG, Lewis TLT, Pinker GD (eds). Gynaecology by ten teachers. 14th ed. London: Edward Arnold, 1985: 210. 4 Office of Population Censuses and Surveys. Cancer statistics registrations 1986. London: HMSO, 1991.

5 Williams C. Ovarian and cervical cancer. BMF 1992; 304: $1501-4$

6 Muir C, Waterhouse J, Mack T, Powell J eds. World Health Organisation, International Agency for Research on Cancer, International Association for Cancer Research. Cancer incidence in five continents. (vol 5). Lyon: International Agency for Research on Cancer, 1987.

7 Chamberlain J. Gynaecological cancers. In: Miller DL, Farmer RDT eds. Epidemiology of diseases. Oxford: Farmer RDT eds. Epidemiology of disease
Blackwell Scientific Publication, 1982: 283.

8 Vessey M, Metcalfe A, Wells C, McPherson K, Westhoff C, Vessey M, Metcalfe A, Wells C, McPherson K, Westhoff C,
Yeates D. Ovarian neoplasms, functional ovarian cysts, and oral contraceptives. BMF 1987; 294: 1518-20.

9 McGowan L, Parent L, Lender W, Norris HJ. The woman at risk of developing ovarian cancer. Gynaecol Oncol 1979; 7: 325-44

10 Ponder BA. Genetic predisposition to cancer. Brit 7 Cancer 1991; 64: 203-4.

11 Osborn RH, de George FV. The ABO blood groups in neoplastic disease of the ovary. Am $f$ Hum Genet 1963; 15: 380-8.

12 Mori $M$, Kiyosawa $\mathrm{H}$, Miyake $\mathrm{H}$. Case-control study of ovarian cancer in Japan. Cancer 1984; 53: 2746-52.

13 Bjorkholm E. Blood group distribution in women with ovarian cancer. Int $\mathcal{f}$ Epidemiol 1984; 13: 15-7.

14 Bjarnason $O$, Tulinius $\mathrm{H}$. Tumours in Iceland. 9. Malignant Bjarnason $\mathrm{O}$, Tulinius $\mathrm{H}$. Tumours in Iceland. 9. Malignant
tumours of the ovary. A histological classification, epidemiological considerations and survival. Acta Pathol Microbiol Immunol Scand 1987; 95: 185-92.

15 Mourant AE, Kopec AC, Domaniewska-Sobczak K. Blood groups and diseases. Oxford: Oxford University Press, 1978.

16 Smith DF, Prieto PA. Forssmann antigen. In: Roitt IM, Delves PH eds. Encyclopedia of immunology. vol 2 . London: Academic Press, 1992: 591-2. 